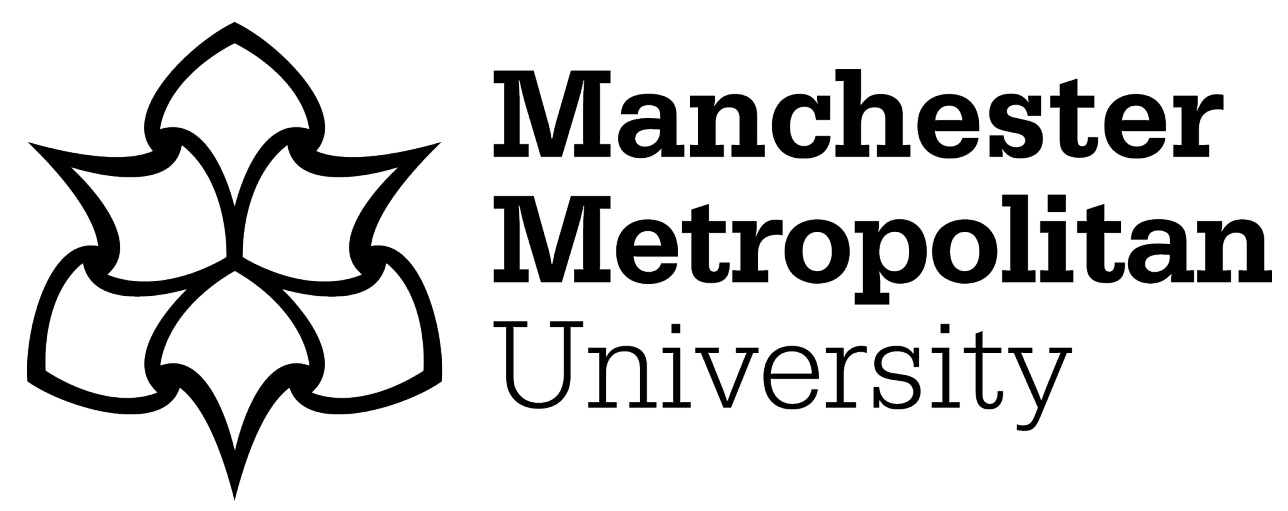

Unsworth, AJ ORCID logoORCID: https://orcid.org/0000-0003-3809-5984, Bye, AP and Gibbins, JM (2017) Platelet-Derived Inhibitors of Platelet Activation. In: Platelets in Thrombotic and Non-Thrombotic Disorders: Pathophysiology, Pharmacology and Therapeutics: an Update. Springer, pp. 541-556. ISBN 9783319474625

Downloaded from: https://e-space.mmu.ac.uk/622754/

Version: Accepted Version

Publisher: Springer

Please cite the published version 


\section{Platelets in Thrombotic and Non-Thrombotic Disorders}

\section{Platelet-derived inhibitors of platelet activation}

\section{A.J.Unsworth*, A.P.Bye*, J.M.Gibbins}

* authors contributed equally

Institute for Cardiovascular and Metabolic Research, School of Biological Sciences, University of Reading, Reading, United Kingdom.

Address for Correspondence: Jonathan Gibbins, Institute for Cardiovascular and Metabolic Research, School of Biological Sciences, University of Reading, Harborne Building, Reading, RG6 6AS, United Kingdom; e-mail: j.m.gibbins@reading.ac.uk.

Tel. +44 (0)1183787082 (Direct)

Fax: +44 (0) 1183787045 


\begin{abstract}
When blood vessels are damaged, circulating platelets come into contact with activating stimuli that trigger aggregation and enable them to form a haemostatic plug. This process is subject to both positive and negative feedback to ensure that platelets respond appropriately to damage and do not form thrombi that totally occlude the vessel. Dysregulation of negative feedback mechanisms is believed to contribute to the increased risk of thrombosis associated with some diseases. Despite the association with thrombosis, platelet derived negative regulators of platelet activation are relatively poorly understood in comparison to mediators of platelet activation. However, it is increasingly apparent that the mechanisms by which platelets restrain activation are diverse and of equal complexity to those that mediate positive signalling. Some regulators, such as RASA3 and JAM-A, act as gatekeepers that must be deactivated for platelet activation to occur. In contrast, regulators that contain ITIMs, such as PECAM-1, are activated following stimulation and mediate negative regulation via phosphatases that restrain activation. Wnt3a and ESAM are thought to directly limit plateletplatelet adhesion by blocking activation of the fibrinogen receptor, integrin $\alpha_{\| b} \beta_{3}$. The various isoforms of PKC expressed by platelets provide a diverse and complex array of inhibitory effects including receptor desensitisation. Many platelet derived inhibitors have been identified but not fully characterised and so questions remain regarding the mechanisms that underlie their effects on platelet activity following their activation, inhibition or genetic disruption. In this chapter the current understanding and recent developments in the field of platelet-derived inhibitors of platelet activation will be discussed.
\end{abstract}




\section{$\underline{\text { Introduction }}$}

Negative regulators of platelet activation are a relatively unexplored aspect of platelet physiology yet have an important role in tempering thrombus development by contributing much needed negative regulation to a process that is amplified by several positive feedback mechanisms. Some negative regulators, such as RASA3 and JAM-A, act as gate keepers that modulate key mediators of activation and provide barriers that must be deactivated to permit full activation and stable thrombus formation. Other negative regulators, such as PECAM-1 and other proteins that signal through ITIMs, come into play once platelets are activated and provide restraining, negative feedback for activatory pathways. Many platelet-derived inhibitors have been identified but not fully characterised and so questions remain regarding the mechanisms that underlie the effects on platelet activity following their activation, inhibition or genetic disruption. However, dysregulation of inhibitory signals is believed to contribute to enhanced risk of thrombosis in diseases such as diabetes and other pathological conditions. In this chapter we have described platelet-derived inhibitors of platelet function that are secreted by or expressed within platelets themselves to provide inhibition or negative regulation to the processes that underpin activation.

\section{ITIM signaling}

Immunoreceptor tyrosine-based inhibitory motif (ITIM) containing receptors are capable, following ligand binding, of triggering cell signalling mechanisms that counteract activation processes. The ITIM consensus sequence L/I/V/S-X-Y-X-X-L/V usually found in the cytoplasmic tail has been identified in several proteins that are expressed in platelets, including PECAM-1, CEACAM, G6b-B, and LILRB2/PIRB which are associated with the negative regulation of platelet activation (Wu and Lian, 1997, Cicmil et al., 2000, Jones et al., 2001, Wong et al., 2009, Alshahrani et al., 2014, Yip et al., 2015, Newland et al., 2007, Mori et al., 2008, Coxon et al., 2012). When ITIM-bearing receptors bind their ligand, the receptors cluster and src family kinases phosphorylate the tyrosine residues in the ITIM motif. The phosphorylated ITIM is then able to recruit negative regulators including phosphatases such as SHP1/SHP2 (Kharitonenkov et al., 1997) and SHIP1/SHIP2 (Bruhns et al., 2000). The recruited phosphatases are localised within close proximity to their substrates, which allows them to inactivate molecules involved in activatory cell signaling including tyrosine kinases and phosphatidylinositol 3,4,5-trisphosphate kinase (PI3K) (Figure 1). ITIMs were initially considered to be the 'off switch' that counteracts the positive signaling initiated by ITAM (consensus sequence $\mathrm{Yxx}_{\mathrm{xx}}(\mathrm{L} / \mathrm{I}) \mathrm{x}_{6-12} \mathrm{Y} \mathrm{Xx}(\mathrm{L} / \mathrm{I})$ ) containing receptors such as the GPVI receptor complex. However, studies have now identified negative regulation of GPCR signaling by PECAM-1 and G6b-B that are independent of ITAM signaling pathways (Newland et al., 2007, Jones et al., 2009) (Figure 1).

\section{PECAM-1}

Platelet endothelial cell adhesion molecule-1 (PECAM-1) is a 130kDa member of the Immunoglobulin superfamily that is expressed on several haematopoetic cells including platelets, monocytes, neutrophils, some types of T cells and endothelial cells and is associated with several biological processes including negative regulation of platelet activation (Newman, 1997). PECAM-1 contains a 574 amino acid extracellular domain that is composed of 6 Ig-like homolog and mediates homophillic interactions with other PECAM-1 molecules. It also contains a short 19 amino acid single transmembrane spanning domain and a 118 amino acid cytoplasmic domain that includes the ITIM (Sun et al., 1996, Newton et al., 1997, Goyert et al., 1986, Lyons et al., 1988). Expression levels of 
PECAM-1 are variable with copy numbers ranging between 5,000-20,000 present at the cell surface per platelet (Jones et al., 2009). PECAM-1 is present in platelet $\alpha$-granules, resulting in an increase in cell surface expression following platelet activation and granule secretion (Hidari et al., 1997, Wu and Lian, 1997, Metzelaar et al., 1991, Jones et al., 2009). PECAM-1 is believed to be activated by homomeric clustering (Thai le et al., 2003) but interactions with other receptors have also been reported (Buckley et al., 1996). Clustering of PECAM-1 to ITAM containing receptors or ligation of PECAM-1 using anti-PECAM-1 antibodies or recombinant human PECAM-1 immunoglobulin chimeras, has been shown to inhibit GPVI, GPIb and GPCR-stimulated platelet aggregation. Activation of PECAM1 has broad effects on signal transduction, including reduced total tyrosine phosphorylation, inositol tris-phosphate production, $\mathrm{Ca}^{2+}$ mobilisation and granule secretion which underpins a reduction in thrombus formation (Cicmil et al., 2002, Jones et al., 2009, Jones et al., 2001, Thai et al., 2003, Rathore et al., 2003). PECAM-1\% platelets exhibit hyper-reactivity when stimulated with low concentrations of collagen and CRP but not thrombin, ADP or PAR receptor agonists. Studies that have measured thrombus formation ex vivo and in vivo using mice deficient in PECAM-1 indicate an inhibitory role for PECAM-1 in the regulation of thrombus formation, as increased thrombus size and stability is observed (Falati et al., 2006).

PECAM-1 is regulated by phosphorylation of its cytoplasmic tail at the tyrosine residues Y663 and Y686 within the ITIM and ITSM (immunoreceptor tyrosine-based switch motif) motifs. PECAM-1 is constitutively phosphorylated at low levels in resting platelets and phosphorylation is increased following anti-PECAM-1 antibody induced crosslinking, but also in response to several platelet agonists including collagen, convulxin, thrombin and GPIb agonists suggesting, that PECAM1 provides a negative feedback mechanism to control the level of platelet activation and thrombus formation (Jackson et al., 1997, Modderman et al., 1994, Cicmil et al., 2000, Jones et al., 2001, Rathore et al., 2003). Phosphorylation of PECAM-1 at the ITIM is mediated by activation of Src family kinases and Fyn, Lyn, Src, Yes and Hck have all been shown to coimmunoprecipitate with PECAM-1 (Cao et al., 1998, Cicmil et al., 2000). Phosphorylated ITIMs provide a binding and activation platform for SH2 domain containing proteins, including phosphatases SHP-1 and SHP-2, SHIP1 and PP2A (Pumphrey et al., 1999, Relou et al., 2003, Henshall et al., 2001) that are associated with the negative regulation of platelet activity. Following activation of GPVI signaling PI3K associates with the LAT signalosome which is located in lipid rafts that are enriched with the phosphoinositide substrates of PI3K. In contrast to LAT, the majority of PECAM-1 molecules are excluded from lipid rafts. Following crosslinking of PECAM-1, SHP2 is recruited to PECAM-1 and associates with PI3K, relocalising PI3K away from lipid rafts and the LAT signalosome, preventing association with and activation of PI3K (Moraes et al., 2010a). Most recently the mechanism by which PECAM-1 negatively regulates responses to non-GPVI agonists such as thrombin and VWF has also been described (Jones et al., 2014). PECAM-1 inhibits fibrinogen binding and secretion stimulated by thrombin but not PAR1 and PAR4 activating peptides, which suggests that PECAM-1 has a role in regulating GPIba, a receptor that recruits thrombin to the platelet plasma membrane facilitating stimulation of PARs (Jones et al., 2012). PECAM-1 was found to mediate the internalisation of GPIba in platelets through dual AKT /glycogen synthase kinase3/dynamin-dependent and $\alpha$ llbß3-dependent mechanisms.

A study looking at the expression patterns of PECAM-1 in platelets has identified that expression levels of PECAM- 1 are variable within the human population with approximately 5,000-20,000 copies estimated to be present at the cell surface. Analysis of the relationship between receptor expression levels and platelet responsiveness to platelet agonists, revealed an inverse relationship between 
levels of PECAM-1 expression and platelet response to stimulation by CRP-XL and ADP (Jones et al., 2009). Although the association is described as modest accounting for $6-10 \%$ of total variability in responses, this was at a similar level of magnitude to that observed for the positive correlation of GPVI or allbß3 expression levels with platelet responsiveness.

Despite the overall negative role for PECAM-1 in the regulation of platelet activity, PECAM-1 signaling in other cell types is associated with the regulation of integrin function, whereby crosslinking of PECAM-1 enhances adhesion mediated by integrins (Tanaka et al., 1992, Piali et al., 1993, Leavesley et al., 1994, Berman et al., 1996, Varon et al., 1998, Chiba et al., 1999, Zhao and Newman, 2001). Studies in human platelets have shown that antibody crosslinking of PECAM-1 enhances adhesion and spreading on fibrinogen (Zhao and Newman, 2001) indicating a positive role for PECAM-1 in the regulation of integrin allb $\beta 3$. Mouse platelets deficient in PECAM-1 show impaired spreading and adhesion on fibrinogen, clot retraction and phosphorylation of focal adhesion kinase, suggesting a defect in integrin $\alpha_{\| 1} \beta_{3}$ outside-in signalling (Wee and Jackson, 2005). It has been hypothesised that a dual role for PECAM-1 could therefore exist, in which it initially functions to suppress platelet activation but once platelets are strongly activated, PECAM-1 positively regulates functions mediated by integrin outside-in signaling (Jones et al., 2012).

High cholesterol significantly increases an individual's risk of atherosclerosis, coronary heart disease, heart attacks and stroke. Statins are widely prescribed as cholesterol lowering drugs and have been shown to reduce platelet activation. It has been described that one possible mechanism by which statins inhibit platelet function is through the activation and regulation of PECAM-1 (Moraes et al., 2013). Treatment of platelets with statin simvastatin showed simvastatin was capable of increasing PECAM-1 phosphorylation and recruitment of SHP-2 to the ITIM which is essential for the negative function of PECAM-1. In further support of statins working through PECAM-1, PECAM-1 deficient mice showed reduced sensitivity to statins compared to WT controls indicating that they must in some way work via PECAM-1.

\section{CEACAM-1 and CEACAM-2}

Carcinoembryonic antigen (CEA)-related cell adhesion molecules, CEACAM1 and CEACAM2 are ITIM containing membrane receptors that are expressed in both human and mouse platelets. CEACAM1 and 2 both contain extracellular glycosylated Ig-domains (four in CEACAM1 and two in CEACAM2), a transmembrane domain and a long cytoplasmic tail that contains the ITIM which is almost identical between the two proteins (Salaheldeen et al., 2012). CEACAM1 is activated following clustering via a homophillic interaction. The endogenous ligand of CEACAM2 has not yet been identified but can be activated by the murine coronavirus mouse hepatitis virus spike glycoprotein(s) (Robitaille et al., 1999). Studies using other cell types including T-cells and epithelial cells (Nagaishi et al., 2006) have shown that CEACAM1 and CEACAM2 use their ITIMs to recruit SHP1 and, to a lesser degree, SHP2 which can then initiate negative regulation of positive signaling pathways (Beauchemin et al., 1997).

Mice deficient in either CEACAM1 or CEACAM-2 show increased adhesion to fibrillar collagen and increased aggregation and secretion evoked by GPVI which indicates a role for both receptors in the negative regulation of GPVI signaling and platelet responses (Wong et al., 2009, Alshahrani et al., 2014). CEACAM2 deficient platelets have also been shown to have increased platelet responses to CLEC-2 agonist Rhodocytin. Platelets deficient in either CEACAM-1 or CEACAM-2 show increased tyrosine phosphorylation of Syk and PLCY2 following stimulation by CRP and also Rhodocytin in 
CEACAM $2 \%$ platelets. Platelets from mice deficient in either CEACAM1 or CEACAM2 display increased thrombus growth in vitro and in vivo suggesting that CEACAM1 and 2, like PECAM1 are negative regulators of platelet GPVI signaling. Also similar to that observed with PECAM-1, it has been recently described that CEACAM1 1 platelets show reduced signaling and activation through $\alpha$ llb $\beta 3$ suggesting an alternative, positive regulatory mechanism for CEACAM1 in platelets (Yip et al., 2015). The role of CEACAM2 in the regulation of integrin $\alpha \mathrm{llb} \beta 3$ is as yet unknown .

\section{G6b-B}

The transmembrane protein G6b was identified through both proteomics and gene expression studies (Macaulay et al., 2007, Senis et al., 2007) and the G6b-B variant was confirmed to be present in platelets (Senis et al., 2007). G6b-B contains an extracellular domain consisting of 125 amino acids and a cytoplasmic tail that contains two ITIM sequences. The endogenous ligand of G6b-B has not yet been identified, but G6b-B has been shown to be constitutively phosphorylated in resting platelets, and this increases following stimulation with GPVI specific agonist collagen related peptide (CRP) or Thrombin (Senis et al., 2007). Treatment of cells expressing G6b-B with pervanadate to inhibit phosphatases enhances tyrosine phosphorylation of G6b-B and the recruitment of SHP1 and SHP2 (de Vet et al., 2001, Coxon et al., 2012), thereby suggesting that G6b-B works via a similar mechanism to other ITIM containing proteins to inhibit platelets. Interestingly, studies using the DT40 cell line show that inhibition of GPVI signaling following G6b-B expression is retained in the absence of both SHP1 and SHP2, and is also retained in the absence of SHIP suggesting redundancy between these phosphatases or the involvement of other inhibitory molecules and mechanisms of action (Mori et al., 2008). Recent studies have identified that G6b-B is capable of interacting with several key signaling molecules, including Csk, Src, Fyn, Syk, PLCY2 and PI3K, and it has been suggested that G6b-B may mediate its inhibitory effects on signaling and platelet activity by redistributing signaling molecules away from their substrates (Coxon et al., 2012). Further evidence of a negative regulatory role for G6b-B in platelets was found by using a crosslinking antibody for G6b-B which caused inhibition of platelet aggregation to CRP, and ADP. No alteration in ADP stimulated $\mathrm{Ca}^{2+}$ signaling was observed suggesting that G6b-B acts downstream of $\mathrm{Ca}^{2+}$ release. This suggests that G6b-B may act via an alternative inhibitory mechanism to that observed downstream of other ITIM containing receptors such as PECAM and CEACAM, where G6b-B is capable of inhibiting signaling events downstream of mobilisation of intracellular $\mathrm{Ca}^{2+}$ (Newland et al., 2007). However, G6b-B deficient mice do not show platelet hyper-reactivity, although this is likely to be attributed to an increase in GPVI receptor shedding, that is observed as a result of enhanced metalloproteinase production in the megakaryocytes of these mice (Mazharian et al., 2012). This indicates an important role for G6b-B in megakaryocytes but the physiological role of G6b-B in platelets remains unclear (Mazharian et al., 2012).

\section{PIRB/LILRB}

The leukocyte immunoglobulin like receptors (LILRs) include two subfamilies, LILRA and LILRB, whilst the LILRA proteins contain an ITAM domain, the LILRB family members are characterised as containing an ITIM. Human platelets express LILRB2 and mouse platelets express its homolog PIRB which contains four cytoplasmic ITIMs (Takai, 2005). Platelets have also been found to express the PIRB ligand ANGPTL2, which is found in alpha granules, which may suggest that autocrine self- negative 
regulation of platelets via PIRB/LILRB2 following their activation may occur (Zheng et al., 2012, Fan et al., 2014). Recent studies have identified that treatment of platelets with purified ANGPTL2 results in an inhibition of their activation to several agonists including CRP, ADP and thrombin while adhesion and spreading on fibrinogen is also inhibited (Fan et al., 2014). PIRB-TM mutant mice, which are unable to mediate intracellular signalling through this receptor, have a hyper-reactive platelet phenotype with increased aggregation evoked by CRP, increased spreading on fibrinogen and increased clot retraction. Key GPVI signaling events following activation by CRP, including phosphorylation of LAT, SLP-76 and PLCY2 are inhibited following ANGPTL2 treatment and increased in PIRB-TM mutants. During adhesion to fibrinogen, phosphorylation of FAK and $\beta 3$ are also enhanced in PIRB-TM mouse platelets. PIRB dependent inhibition of GPVI and integrin $\alpha$ llb $\beta 3$ signaling has been linked to the recruitment of SHP1 and SHP2 phosphatases, as both are recruited to PIRB and are phosphorylated following treatment with ANGPTL2 but their recruitment and phosphorylation is reduced in PIRB-TM expressing mice (Fan et al., 2014).

\section{$\underline{\text { Intracellular nuclear receptors }}$}

Several intracellular nuclear receptors have been identified and characterised in human platelets including the peroxisome proliferator activating receptors (PPAR)s, PPAR $\alpha, P P A R \beta / \delta$ and PPAR $\gamma$, the retinoid $X$ receptor (RXR), liver $X$ receptor (LXR), farnesoid $X$ receptor (FXR) and Glucocorticoid receptor (GR) (Moraes et al., 2010c, Moraes et al., 2007, Spyridon et al., 2011, Moraes et al., 2005b, Ali et al., 2006a) (Figure 2).

\section{Peroxisome proliferator activated receptors}

PPARs represent three nuclear receptor isoforms, PPAR $\alpha$, PPAR $\beta$ and PPAR $($ Berry et al., 2003) which are involved in cell development, differentiation, cholesterol and fatty acid metabolism and glucose homeostasis (O'Brien et al., 2007, Barak et al., 1999, Kersten et al., 2000). All three isoforms of PPAR upon binding to their ligands are capable of heterodimerising with RXR another nuclear receptor and all have been identified to have acute non-genomic negative regulatory effects in human platelets.

Treatment of platelets with ligands for PPAR $\alpha$, such as fenofibrate and statins were found to increase intracellular levels of CAMP resulting in inhibition of ADP-stimulated platelet activation. Fenofibrite was also found to inhibit platelet activation and increase bleeding time in WT mice but not mice deficient in PPARa ${ }^{-1}$ (Ali et al., 2009a). Following activation by fenofibrite, PPAR $\alpha$ was found to associate with PKC $\alpha$ a key positive mediator of platelet activation, and it is thought that this interaction may in part contribute to the negative regulation of platelet activation that is observed following treatment with PPARa ligands.

PPAR $\beta / \delta$ has been shown to decrease plaque formation and attenuate the progression of atherosclerosis (Lee et al., 2003). Studies using synthetic agonists for PPARB/ $\delta$, GW0742 and L-165041 have identified inhibitory actions for PPARB/ $\delta$ ligands on the mobilisation of intracellular $\mathrm{Ca}^{2+}$ and platelet aggregation following stimulation by ADP and other platelet agonists (Ali et al., 2006b). $\mathrm{PGI}_{2}$ a key inhibitory mediator of platelet function is also a ligand for PPAR $/ \delta$ and some of its inhibitory effects on platelet activity could be mediated through PPAR $\beta / \delta$ (Forman et al., 1997). As with PPAR $\alpha$, treatment of platelets with agonists of PPAR $/ \delta$ result in an increase in CAMP levels and PKC $\alpha$ has 
been identified as a potential binding partner of the receptor and a potential mechanism by which PPAR $/ \delta$ may regulate platelet reactivity (Ali et al., 2009b).

Agonists of PPARY, the thiazolidinediones are currently in use for the treatment of type 2 diabetes mellitus and have been observed clinically to have cardio-protective properties and reduce the risk of myocardial infarction (Dormandy et al., Sauer et al., 2006). The emerging role of PPARY agonists as negative regulators of platelet function may provide a mechanistic basis for this observation. A clinical study that measured platelet function in patients with coronary heart disease treated with rosiglitazone reported long-term anti-platelet effects with down-regulation of p-selectin exposure and granule secretion in treated patients (Sidhu et al., 2004). Treatment of platelets ex vivo with the endogenous agonist of PPARY, $15 \mathrm{dPGJ}_{2}$ or the synthetic agonist rosiglitazone results in reduced platelet responses including granule secretion and thromboxane $B_{2}\left(T_{x} B_{2}\right)$ synthesis in response to thrombin or ADP (Akbiyik et al., 2004). Agonists of PPARy have also been shown to suppress platelet activation stimulated by GPVI agonists, with platelet aggregation, granule secretion and mobilisation of intracellular $\mathrm{Ca}^{2+}$ inhibited following treatment with $15 \mathrm{dPGJ}_{2}$ (Moraes et al., 2010c). Treatment with PPARY agonists results in reduced thrombus formation in vitro and in vivo (Moraes et al., 2010c, Li et al., 2005).

Additionally statins, that are routinely prescribed as cholesterol lowering drugs have also been shown to activate PPARs (Ali et al., 2009a). Treatment of human whole blood with the statins, pravastatin, fluvastin and simvastin all resulted in a reduction in platelet aggregation to ADP. This decrease in platelet activity was attributed to a PPAR mediated increase in cAMP levels.

\section{RXR}

Human platelets and megakaryocytes express RXR $\alpha$ and RXR $\beta$ (Moraes et al., 2007). Treatment of platelets with the endogenous agonist of RXR, 9-cis-retenoic acid or the synthetic agonist, methoprene acid, results in an inhibition of Gq protein coupled induced platelet aggregation that is stimulated by ADP and thromboxane A2 (TXA2). It is thought RXR regulates GPCR mediated platelet activation by binding to $\mathrm{Gq}$ in a ligand-dependent manner inhibiting $\mathrm{Gq}$ induced rac activation and intracellular $\mathrm{Ca}^{2+}$ release (Moraes et al., 2007).

LXR

The LXR $\alpha$ and LXR $\beta$ isoforms of LXR are implicated in the regulation of fatty acid, cholesterol and glucose homeostasis (Viennois et al., 2012, Viennois et al., 2011) and agonists for LXR have been described to have anti-inflammatory effects and be atheroprotective (Joseph et al., 2002, Tangirala et al., 2002). LXR $\beta$ has been identified as the isoform present in platelets (Spyridon et al., 2011), and endogenous ligands for the LXR receptors include oxysterols (oxygenated derivatives of cholesterol) and several synthetic agonists including GW3965 and T0901317 also exist (Gabbi et al., 2014, Wójcicka et al., 2015). Treatment of platelets with synthetic agonist GW3965 results in inhibition of platelet activation, including aggregation, secretion and integrin activation stimulated by collagen, CRP or thrombin. GW3965-treated mice form smaller, less stable thrombi following laser injury of the cremaster arterioles. LXR has also been shown to interact with several components of the GPVI signaling pathway following treatment with GW3965, including Syk and PLCY2, resulting in decreased phosphorylation and signaling (Spyridon et al., 2011, Moraes et al., 2010b). 


\section{Glucocorticoid receptor}

The glucocorticoid receptor (GR) is activated by glucocortoid steroid hormones, a major class of antiinflammatory hormones, and prednisolone a synthetic derivative of cortisol that has been used to understand the role of $G R$ in the regulation of platelet function. Platelets preincubated with prednisolone prior to agonist stimulation show reduced aggregation and $\mathrm{TxB}_{2}$ release in response to both ADP and TXA 2 mimetic U46619 which could be reversed following treatment with a GR antagonist mifepristone (Moraes et al., 2005a). However, the mechanism underlying negative regulation of platelet function by GR agonists is still poorly understood.

\section{$\underline{\text { Negative regulators of small GTPases and integrin } \alpha_{\| 1 \mathrm{~b}} \beta_{3} \text { activation }}$}

One of the key processes that underpin thrombus formation is the activation of the integrin $\alpha$ llb $\beta 3$. Activation of $\alpha$ llb $\beta 3$ results in a conformational change in the receptor that enables fibrinogen binding and aggregation, and also initiates outside in signaling which sustains platelet activation. Suppression of integrin $\alpha_{\| 1 b} \beta_{3}$ activation prevents inappropriate platelet aggregation and excessive thrombus formation that can cause vessel occlusion (Figure 3).

\section{RASA3}

RASA3 has recently been identified as an important inhibitor of integrin $\alpha_{11 b} \beta_{3}$ activation (Stefanini et al., 2015) through the regulation of RAP1b which is a critical regulator of integrin function in platelets (Chrzanowska-Wodnicka et al., 2005, Stefanini et al., 2012). Rap1b is positively regulated by the $\mathrm{Ca}^{2+}$ sensing guanine exchange factor (GEF), CAIDAG-GEF1 (Crittenden et al., 2004) and RASA3 provides opposing, negative regulation that maintains platelets in a quiescent state when at resting $\left[\mathrm{Ca}^{2+}\right]_{i}$ (Stefanini et al., 2015). RASA3 deficiency is embryonically lethal in mice but homozygous expression of a mutated form of RASA3 with impaired activity results in viable animals with platelet hyperreactivity that can be rescued by simultaneous deficiency of CALDAG-GEF1. However, integrin $\alpha_{\| 1} \beta_{3}$ activation in the double knockout mouse occurs independently of P2Y12 and PI3K.

\section{JAM-A}

JAM-A is a transmembrane protein of the CTX family that is expressed on cell surface and has been identified in platelets. Mice deficient in JAM-A display increased aggregation to several platelet agonists, increased spreading on fibrinogen and clot retraction and increased thrombus formation indicating a role for JAM-A in the negative regulation of $\alpha$ llbB3 (Naik et al., 2012). JAM-A is phosphorylated in resting platelets and associates with $\alpha_{\| 1} \beta_{3}$ (Naik et al., 2012). JAM-A is proposed to keep the integrin inactive by binding C-terminal src kinase (Csk) via its $\mathrm{SH} 2$ domain which recruits it to the integrin. Recruitment of Csk ensures that c-Src, which is associated with the integrin, remains in an inactive state through phosphorylation of the inhibitory Y529 in c-Src's regulatory domain (Naik et al., 2014). On platelet activation JAM-A is dephosphorylated, Csk dissociates enabling activation of cSrc and integrin allbß3 activation.

Studies using ApoE deficient mice that model high cholesterol and atherosclerosis, have highlighted the importance of the platelet inhibitory receptor JAM-A in the development of the pathological disease state. A recent study has shown that platelet deficiency in the inhibitory receptor JAM-A in 
ApoE ${ }^{-/}$mice fed a high fat diet, increases aortic plaque formation and recruitment of inflammatory cells. Suggesting that platelet hyperreactivity such as that observed in JAM-A ${ }^{-1}$ platelets can contribute to atherosclerotic plaque formation (Karshovska et al., 2015).

\section{ESAM}

ESAM, a transmembrane glycoprotein, like JAM-A is a member of the CTX family and is also suggested to be involved in the negative regulation of adhesion and integrin $\alpha$ llb $\beta 3$ outside-in signaling. In contrast to JAM-A, ESAM appears to negatively regulate integrin $\alpha \mathrm{llb} \beta 3$ and limit its activity following platelet activation. ESAM is contained in the alpha granules and is translocated to the cell surface on activation (Nasdala et al., 2002). Mouse platelets deficient in ESAM show increased aggregation to GPCR agonists, inhibition of clot retraction, increased thrombus formation in vivo and reduced tail bleeding (Stalker et al., 2009). The mechanism by which ESAM functions is currently unknown, although interaction via its PDZ domain with NHERF-1, a scaffold protein highlights possible interaction with and regulation of several proteins, including GPCRs (Hall et al., 1998), G proteins and PLCß (Rochdi et al., 2002) and components of the cytoskeleton (Shenolikar et al., 2004).

\section{Wnt3a}

Wnt3a is a glycoprotein that is released from endothelial cells (Goodwin et al., 2006) and also from TRAP stimulated platelets, enabling platelets to self-regulate and limit activation (Steele et al., 2009). Treatment of platelets with Wnt3a results in an inhibition of platelet adhesion and shape change, reduced dense granule secretion and reduced RhoA activation leading to diminished integrin $\alpha_{11 b} \beta_{3}$ activation and aggregation. In platelets, Wnt3a is thought to exert its effects through activation of the canonical Wnt- $\beta$-catenin signaling pathway components of which also appear to be present in platelets (Semenov et al., 2007, Macdonald et al., 2007, Huang and He, 2008). In other cell types $\beta$ catenin has been shown to play a role in the regulation of cell adhesion, where it is involved in supporting the interaction of cadherins to the cytoskeleton (Huang and He, 2008). Negative regulation of platelet activation via Wnt3a signaling is thought to occur through regulation of small GTPase activity, including Rap1, Cdc42, Rac1, RhoA (Steele et al., 2012). It is thought that by favouring the GDP-bound state of Rap1 and Rho via the regulation of RAP1GAP and RhoA GTPase activity, whilst increasing levels of Cdc42 and Rac1 GTP levels, Wnt3a inhibits integrin $\alpha$ llb $\beta 3$ adhesion and spreading.

\section{Neuropilin-1-plexin A complex}

Semaphorin 3A exists as a soluble covalently bound homodimer and is secreted by vascular endothelial cells (Serini et al., 2003). Semaphorin 3A negatively regulates platelet function through binding to the neuropilin-1- plexin A receptor complex which has been identified in platelets (Takahashi et al., 1999, Tamagnone et al., 1999, Kashiwagi et al., 2005). Semaphorin 3A treatment inhibits platelet function, possibly through regulation of integrin $\alpha \mathrm{llb} \beta 3$ as activation of the integrin, aggregation and adhesion and spreading evoked by several platelet agonists are impaired. The exact mechanisms by which Semaphorin 3A inhibits platelet function has not been fully elucidated, although inhibition of the GTPase Rac- 1 appears to be a key regulatory step in the negative regulation of $\alpha \mathrm{llb} \beta 3$ and cytoskeletal rearrangements (Kashiwagi et al., 2005).

\section{Cyclic nucleotide signaling}


Cyclic nucleotides CAMP and CGMP are well established inhibitors of platelet activation. Endothelium derived prostacyclin (PGI2) and nitric oxide (NO) activate the production of CAMP and CGMP respectively and play essential roles in keeping platelets in the resting state in the circulation. The regulation of platelets by these molecules is discussed in detail in Chapter X.

\section{cAMP and Protein kinase $\mathrm{A}$}

$\mathrm{PGI}_{2}$ binds to and activates the Prostaglandin receptor on the platelet surface (Dutta-Roy and Sinha, 1987), which then propagates inhibitory signaling through the activation of Gs subunits which activates adenylyl cyclase and stimulates the production of cAMP from ATP (Gorman et al., 1977). CAMP activates CAMP dependent protein kinase A (PKA). Following platelet activation by agonists such as ADP and thrombin, adenylyl cyclase activity is inhibited and cAMP levels reduced through Gi signaling (Jantzen et al., 2001, Yang et al., 2002). PKA phosphorylates multiple target proteins that maintain platelets in an inactive resting state by limiting platelet activation. Several substrates of PKA have been well characterised and are linked to the negative regulation of platelets, including VASP which is involved in cytoskeletal rearrangements (Waldmann et al., 1987, Butt et al., 1994), inhibition of Raplb a key regulator of integrin allbß3 affinity (Schultess et al., 2005, Miura et al., 1992), Inositol trisphosphate receptor $\left(\mathrm{IP}_{3} \mathrm{R}\right)$ which is involved in $\mathrm{Ca}^{2+}$ regulation (Cavallini et al., 1996) and the thromboxane A2 receptor (Reid and Kinsella, 2003). Other targets also include Ga13 (Manganello et al., 1999), GPIbß (Wardell et al., 1989), and CALDAG-GEFI (Schultess et al., 2005)

Recent studies have identified a cAMP independent mechanism of PKA activation following stimulation of platelets by thrombin or collagen (Gambaryan et al., 2010). In resting platelets a population of platelet PKA appears to be associated with NFKB-IKB $\alpha$. Following stimulation by collagen or thrombin the catalytic subunit of PKA dissociates from NFKB-IKB $\alpha$ and is activated, enabling phosphorylation and activation of its substrates. This identifies an inhibitory feedback mechanism that prevents excessive platelet activation in response to stimuli (Gambaryan et al., 2010).

\section{Regulation of cGMP and PKG by Platelet-derived NO}

The cyclic nucleotide cGMP is a key negative regulator of platelet activation that inhibits platelets to keep them in the resting state in the healthy vasculature (Smolenski, 2012). Endothelial release of nitric oxide (NO) keeps platelets inactive by regulating their intracellular levels of cGMP (Mellion et al., 1981, Radomski et al., 1987). Following the synthesis and release of NO from the healthy endothelium, NO crosses the platelet plasma membrane and binds to and activates, soluble guanyl cyclase (sGC), leading to the increased production of cGMP from GTP and activation of protein kinase $G(P K G)$. Levels of cGMP are controlled by the phosphodiesterase, PDE5A which is present in platelets (Haslam et al., 1999). Platelets deficient in PKG are insensitive to cGMP-mediated inhibition of intracellular $\mathrm{Ca}^{2+}$ release (Eigenthaler et al., 1993) and PKG knock-out mice have a prothrombotic phenotype and exhibit increased intravascular adhesion and aggregation following ischaemia (Massberg et al., 1999).

Platelets are also considered to be a source of NO. The mechanism by which platelets synthesise NO and whether or not it is of physiological importance is however, still an area of contention. Although NO itself is an established negative regulator of platelet function, the vascular endothelium has traditionally been considered the dominant source of NO within blood vessels. Platelets have been reported to express two nitric oxide synthase (NOS) isoforms, iNOS and eNOS but generate less NO 
than endothelial cells (Radomski et al., 1990b) although the presence of eNOS is contentious (Gambaryan et al., 2008). Studies into the effects of platelet-derived NO on platelet function using iNOS/eNOS knockout mice have more recently suggested eNOS it is not a major regulator of platelet function (Gambaryan et al., 2008, Tymvios et al., 2009). There is evidence that platelets can produce NO from nitrate although further research is needed to understand the mechanism (Apostoli et al., 2014). Platelet NO production is inducible and is mediated by $\mathrm{Ca}^{2+}$ elevation (Radomski et al., 1990b) and is therefore stimulated by many platelet agonists such as ADP and arachidonic acid. However, the question of whether platelet-derived NO can inhibit platelet aggregation is a source of debate (Gkaliagkousi et al., 2007) with some reports describing platelet-derived NO-mediated inhibition (Radomski et al., 1990b, Radomski et al., 1990a) and others reporting no effect (Thomas et al., 1990, Thompson et al., 1986).

Defects in CAMP/cGMP signalling pathways have the potential to contribute to platelet hyperreactivity in cardiovascular disease including ischemic heart disease, heart failure and diabetes where the reduced sensitivity of platelets to the inhibitory effects of NO contributes to platelet hyperreactivity (Chirkov and Horowitz, 2007). Platelets from patients with type 2 diabetes mellitus and insulin insensitivity for example, are associated with reduced sensitivity of platelets to NO or prostacyclin and consequently greater levels of platelet reactivity. Removal of the negative inhibitory signal from these endothelial mediators, results in the failure to restrain the platelets activatory nature favouring platelet activation. Additionally a number of individuals with genetic abnormalities in prostacyclin signaling have reduce CAMP levels, resulting in hyperreactive platelets and a prothrombotic state, and defects in $\mathrm{SGC}$ function are linked to an increase prevelance of ischemic heart disease, heart failure and diabetes (Van Geet et al., 2009). In contrast patients with hypersensitivity to prostacyclin signaling, as a result of increased activity of Gs proteins show an increased risk of bleeding which is attributed to increased CAMP levels and an increased inhibition of platelet function (Van Geet et al., 2009). It is also suggested that in patients with obesity in addition to defects in SGC function, CAMP synthesis may also be altered and defects in downstream effectors of CAMP and cGMP signaling may contribute to platelet hyperreactivity (Russo et al., 2010).

\section{Other mechanisms of platelet inhibition}

\section{Phosphatases}

Protein modification by phosphorylation is a key mechanism of signal transduction in platelets. Phosphorylation is a reversible post-translational modification that enables regulation of signal transduction and platelet function by phosphatase dependent dephosphorylation of key signaling proteins. Phosphatases are key mediators of several negative signaling pathways in platelets such as those exhibited by the ITIM containing receptors. Protein tyrosine phosphatases such as SHP1 and SHP2, SHIP1 and SHIP2, PP2, PTEN and TULA2 have well established roles in the negative regulation of platelet signaling, in general negatively regulating receptor proximal signaling events leading to reduced mobilisation of $\mathrm{Ca}^{2+}$, granule secretion and integrin activation (Senis, 2013). SHP2 is well established for its roles in the negative regulation of platelet signaling events downstream of the majority of platelet agonists, including GPVI and GPCRs (Ma et al., 2012, Jackson et al., 1997). These observations are supported by studies using mouse platelets deficient in SHP2 which show enhanced activation to fibrinogen (Mazharian et al., 2013). The histidine phosphatase TULA, dephosphorylates and inactivates Syk preventing further downstream signaling (Thomas et al., 2010). TULA deficient 
mice platelets show increased hyperreactivity to GPVI agonists, and also increased thrombus formation and reduced bleeding times. The phosphoinositide phosphatases SHIP-1 and PTEN are involved in the regulation of PI3-kinase function through alteration of the phosphoinositol cycle (Laurent et al., 2014). PTEN-deficient platelets which show hyper-responsiveness to collagen, exhibit increased PI3K activity and show reduced bleeding times in vivo. Finally the serine/threonine kinase phosphatase PP2A is involved in the negative regulation of integrin $\alpha_{11 b} \beta_{3}$ function and signaling (Pradhan et al., 2010, Gushiken et al., 2008). PP2A mediates dephosphorylation of PKCZ and PTP-1B which reduces Src phosphorylation and activation (Mayanglambam et al., 2011, Pradhan et al., 2010, Gushiken et al., 2008). It is important to note, however, that whilst several phosphatases are associated with negative regulation of platelet function, many positive regulatory functions for phosphatases have been identified in platelets (Senis, 2013).

\section{Receptor desensitisation}

Platelets can regulate and limit their responsiveness to platelet agonists, through desensitisation of their receptors following agonist stimulation. ADP for example is a critical secondary mediator of platelet signaling, yet despite this it has been shown that platelets desensitise following continued exposure to ADP (Mundell et al., 2006, Hardy et al., 2005, Cunningham et al., 2013). This diminished response is attributed to desensitisation of both the P2Y1 and P2Y12 receptors via agonist mediated internalisation of each receptor. Studies using both platelets and 1321N1 cells have identified that the P2Y1 and P2Y12 receptors are desensitised by different mechanisms following platelet agonist stimulation. Desensitisation of the P2Y1 receptor is mediated by both classical and novel isoforms of protein kinase $\mathrm{C}$ (PKC), whilst $\mathrm{P} 2 \mathrm{Y} 12$ desensitisation is mediated by $\mathrm{G}$ protein coupled receptor kinase and the novel isoforms of PKC (Hardy et al., 2005).

\section{PKC isoforms}

Protein kinase C (PKC), a family of serine/threonine kinases regulate many aspects of platelet signaling. The different isoforms of PKC are classified into three different subtypes classical, novel and atypical isoforms, according to their structure and mechanism of regulation. Several isoforms have been identified in human platelets although expression of some isoforms is controversial (Newton, 1997, Mellor and Parker, 1998, Murugappan et al., 2004, Buensuceso et al., 2005, Hall et al., 2008, Pears et al., 2008, Konopatskaya et al., 2009, Bynagari et al., 2009, Nagy et al., 2009, Harper and Poole, 2010). Historically the PKC family were considered to play an overall positive role in the regulation of platelet activity, as broad spectrum PKC inhibitors were shown to inhibit granule secretion, $\mathrm{TXA}_{2}$ synthesis, integrin activation, aggregation and thrombus formation (Harper and Poole, 2010). However, negative regulatory roles have subsequently also been identified for the PKC family. Studies using broad spectrum inhibitors have also identified negative roles in the regulation of receptor desensitisation (see section on receptor desensitisation) and $\mathrm{Ca}^{2+}$ release, and studies using isoform specific deficient mice have identified negative regulatory roles for the novel isoforms PKC $\delta$ and PKCO (Harper and Poole, 2010).

Transgenic mice deficient in PKC $\delta$ have identified a negative regulatory role for PKC $\delta$ in the regulation of integrin $\alpha \mathrm{llb} \beta 3$ outside-in signaling and filopodia formation on fibrinogen due to an interaction between PKC $\delta$ and VASP (Pula et al., 2006). PKC has also been shown to negatively regulate GPVI induced platelet responses, as platelets from PKC $\delta$ deficient mice have enhanced aggregation and dense granule secretion in comparison to WT controls. This was also confirmed in human platelets 
using a cell permeable peptide that is designed to block the interaction of PKC $\delta$ and its RACK, $\delta(V 1-1)$ TAT (Chari et al., 2009). Contrasting reports however, also exist as other groups found no abnormality in GPVI-dependent dense granule secretion in PKC $\delta^{-/-}$platelets (Pula et al., 2006). PKC $\delta$ deficient platelets generate larger thrombi when measured in vitro but not when measured in vivo (Gilio et al., 2010, Chari et al., 2009). The overall role of PKC $\delta$ has therefore been difficult to define, possibly as a consequence of diverse positive and negative regulatory roles played by this PKC isoform.

Studies that have utilised PKCO isoform-specific inhibitors have identified negative roles for PKCO in several processes in GPVI-induced platelet activation, including aggregation, $\alpha$-granule secretion, $\alpha_{\| 1} \beta_{3}$ activation and changes in intracellular $\mathrm{Ca}^{2+}$ levels, as all were increased following treatment of platelets with the inhibitor. Studies that have utilised PKCO deficient mice have generated conflicting reports of both positive and negative roles in the regulation of platelet activation (Hall et al., 2008, Nagy et al., 2009, Harper and Poole, 2009, Cohen et al., 2011, Unsworth et al., 2012, Harper and Poole, 2010, Gilio et al., 2010). These differences have been attributed to different experimental conditions whereby PKCO may have a negative role following exposure to low agonist concentrations, and a positive role following exposure to higher concentrations of platelet agonists (Hall et al., 2008, Nagy et al., 2009, Cohen et al., 2011).

\section{Conclusion}

Platelet-derived mediators of negative regulation all function to limit or restrict platelet activation, yet are mechanistically diverse and affect pathways involved in many different processes (Figure 4). While many negative regulators have been identified, many of the processes that they regulate to achieve platelet inhibition are not yet fully characterised. However, it is becoming increasingly clear that negative regulatory mechanisms rival the complexity of the positive regulators of platelet activation. The key challenge in the field of inhibitory platelet signalling will be to establish the physiological and pathological importance of these proteins, their potential as drug targets and their role in determining disease risk.

\section{$\underline{\text { References }}$}

AKBIYIK, F., RAY, D. M., GETTINGS, K. F., BLUMBERG, N., FRANCIS, C. W. \& PHIPPS, R. P. 2004. Human bone marrow megakaryocytes and platelets express PPAR $\gamma$, and PPAR $\gamma$ agonists blunt platelet release of CD40 ligand and thromboxanes. Blood, 104, 1361-1368.

ALI, F. Y., ARMSTRONG, P. C., DHANJI, A.-R. A., TUCKER, A. T., PAUL-CLARK, M. J., MITCHELL, J. A. \& WARNER, T. D. 2009a. Antiplatelet actions of statins and fibrates are mediated by PPARs. Arteriosclerosis, thrombosis, and vascular biology, 29, 706-711.

ALI, F. Y., DAVIDSON, S. J., MORAES, L. A., TRAVES, S. L., PAUL-CLARK, M., BISHOP-BAILEY, D., WARNER, T. D. \& MITCHELL, J. A. 2006a. Role of nuclear receptor signaling in platelets: antithrombotic effects of PPARbeta. FASEB J, 20, 326-8.

ALI, F. Y., DAVIDSON, S. J., MORAES, L. A., TRAVES, S. L., PAUL-CLARK, M., BISHOP-BAILEY, D., WARNER, T. D. \& MITCHELL, J. A. 2006b. Role of nuclear receptor signaling in platelets: antithrombotic effects of PPAR $\beta$. The FASEB Journal, 20, 326-328.

ALI, F. Y., HALL, M. G., DESVERGNE, B., WARNER, T. D. \& MITCHELL, J. A. 2009b. PPARß/ס Agonists Modulate Platelet Function via a Mechanism Involving PPAR Receptors and Specific Association/Repression of PKCa-Brief Report. Arteriosclerosis, Thrombosis, and Vascular Biology, 29, 1871-1873.

ALSHAHRANI, M. M., YANG, E., YIP, J., GHANEM, S. S., ABDALLAH, S. L., DEANGELIS, A. M., O'MALLEY, C. J., MOHEIMANI, F., NAJJAR, S. M. \& JACKSON, D. E. 2014. CEACAM2 negatively regulates 
hemi (ITAM-bearing) GPVI and CLEC-2 pathways and thrombus growth in vitro and in vivo. Blood, 124, 2431-41.

APOSTOLI, G. L., SOLOMON, A., SMALLWOOD, M. J., WINYARD, P. G. \& EMERSON, M. 2014. Role of inorganic nitrate and nitrite in driving nitric oxide-cGMP-mediated inhibition of platelet aggregation in vitro and in vivo. J Thromb Haemost, 12, 1880-9.

BARAK, Y., NELSON, M. C., ONG, E. S., JONES, Y. Z., RUIZ-LOZANO, P., CHIEN, K. R., KODER, A. \& EVANS, R. M. 1999. PPAR gamma is required for placental, cardiac, and adipose tissue development. Mol Cell, 4, 585-95.

BEAUCHEMIN, N., KUNATH, T., ROBITAILLE, J., CHOW, B., TURBIDE, C., DANIELS, E. \& VEILLETTE, A. 1997. Association of biliary glycoprotein with protein tyrosine phosphatase SHP-1 in malignant colon epithelial cells. Oncogene, 14, 783-90.

BERMAN, M. E., XIE, Y. \& MULLER, W. A. 1996. Roles of platelet/endothelial cell adhesion molecule-1 (PECAM-1, CD31) in natural killer cell transendothelial migration and beta 2 integrin activation. J Immunol, 156, 1515-24.

BERRY, E. B., EYKHOLT, R., HELLIWELL, R. J., GILMOUR, R. S., MITCHELL, M. D. \& MARVIN, K. W. 2003. Peroxisome proliferator-activated receptor isoform expression changes in human gestational tissues with labor at term. Molecular Pharmacology, 64, 1586-1590.

BRUHNS, P., VELY, F., MALBEC, O., FRIDMAN, W. H., VIVIER, E. \& DAERON, M. 2000. Molecular basis of the recruitment of the SH2 domain-containing inositol 5-phosphatases SHIP1 and SHIP2 by fcgamma RIIB. J Biol Chem, 275, 37357-64.

BUCKLEY, C. D., DOYONNAS, R., NEWTON, J. P., BLYSTONE, S. D., BROWN, E. J., WATT, S. M. \& SIMMONS, D. L. 1996. Identification of alpha $v$ beta 3 as a heterotypic ligand for CD31/PECAM-1. J Cell Sci, 109 ( Pt 2), 437-45.

BUENSUCESO, C. S., OBERGFELL, A., SORIANI, A., ETO, K., KIOSSES, W. B., ARIAS-SALGADO, E. G., KAWAKAMI, T. \& SHATTIL, S. J. 2005. Regulation of outside-in signaling in platelets by integrin-associated protein kinase $\mathrm{C}$ beta. J Biol Chem, 280, 644-53.

BUTT, E., ABEL, K., KRIEGER, M., PALM, D., HOPPE, V., HOPPE, J. \& WALTER, U. 1994. CAMP- and CGMP-dependent protein kinase phosphorylation sites of the focal adhesion vasodilatorstimulated phosphoprotein (VASP) in vitro and in intact human platelets. J Biol Chem, 269, 14509-17.

BYNAGARI, Y. S., NAGY, B., JR., TULUC, F., BHAVARAJU, K., KIM, S., VIJAYAN, K. V. \& KUNAPULI, S. P. 2009. Mechanism of activation and functional role of protein kinase Ceta in human platelets. J Biol Chem, 284, 13413-21.

CAO, M. Y., HUBER, M., BEAUCHEMIN, N., FAMIGLIETTI, J., ALBELDA, S. M. \& VEILLETTE, A. 1998. Regulation of mouse PECAM-1 tyrosine phosphorylation by the Src and Csk families of protein-tyrosine kinases. J Biol Chem, 273, 15765-72.

CAVALLINI, L., COASSIN, M., BOREAN, A. \& ALEXANDRE, A. 1996. Prostacyclin and sodium nitroprusside inhibit the activity of the platelet inositol 1,4,5-trisphosphate receptor and promote its phosphorylation. J Biol Chem, 271, 5545-51.

CHARI, R., GETZ, T., NAGY, B., JR., BHAVARAJU, K., MAO, Y., BYNAGARI, Y. S., MURUGAPPAN, S., NAKAYAMA, K. \& KUNAPULI, S. P. 2009. Protein kinase C[delta] differentially regulates platelet functional responses. Arterioscler Thromb Vasc Biol, 29, 699-705.

CHIBA, R., NAKAGAWA, N., KURASAWA, K., TANAKA, Y., SAITO, Y. \& IWAMOTO, I. 1999. Ligation of CD31 (PECAM-1) on endothelial cells increases adhesive function of alphavbeta3 integrin and enhances beta1 integrin-mediated adhesion of eosinophils to endothelial cells. Blood, 94, 1319-29.

CHIRKOV, Y. Y. \& HOROWITZ, J. D. 2007. Impaired tissue responsiveness to organic nitrates and nitric oxide: a new therapeutic frontier? Pharmacol Ther, 116, 287-305.

CHRZANOWSKA-WODNICKA, M., SMYTH, S. S., SCHOENWAELDER, S. M., FISCHER, T. H. \& WHITE, G. C., 2ND 2005. Rap1b is required for normal platelet function and hemostasis in mice. J Clin Invest, 115, 680-7. 
CICMIL, M., THOMAS, J. M., LEDUC, M., BON, C. \& GIBBINS, J. M. 2002. Platelet endothelial cell adhesion molecule-1 signaling inhibits the activation of human platelets. Blood, 99, 137-44.

CICMIL, M., THOMAS, J. M., SAGE, T., BARRY, F. A., LEDUC, M., BON, C. \& GIBBINS, J. M. 2000. Collagen, convulxin, and thrombin stimulate aggregation-independent tyrosine phosphorylation of CD31 in platelets. Evidence for the involvement of Src family kinases. J Biol Chem, 275, 27339-47.

COHEN, S., BRAIMAN, A., SHUBINSKY, G. \& ISAKOV, N. 2011. Protein kinase C-theta in platelet activation. FEBS Lett, 585, 3208-15.

COXON, C. H., SADLER, A. J., HUO, J. \& CAMPBELL, R. D. 2012. An investigation of hierachical protein recruitment to the inhibitory platelet receptor, G6B-b. PLoS One, 7, e49543.

CRITTENDEN, J. R., BERGMEIER, W., ZHANG, Y., PIFFATH, C. L., LIANG, Y., WAGNER, D. D., HOUSMAN, D. E. \& GRAYBIEL, A. M. 2004. CalDAG-GEFI integrates signaling for platelet aggregation and thrombus formation. Nat Med, 10, 982-6.

CUNNINGHAM, M. R., NISAR, S. P. \& MUNDELL, S. J. 2013. Molecular mechanisms of platelet P2Y(12) receptor regulation. Biochem Soc Trans, 41, 225-30.

DE VET, E. C., AGUADO, B. \& CAMPBELL, R. D. 2001. G6b, a novel immunoglobulin superfamily member encoded in the human major histocompatibility complex, interacts with SHP-1 and SHP-2. J Biol Chem, 276, 42070-6.

DORMANDY, J. A., CHARBONNEL, B., ECKLAND, D. J. A., ERDMANN, E., MASSI-BENEDETTI, M., MOULES, I. K., SKENE, A. M., TAN, M. H., LEFÈBVRE, P. J., MURRAY, G. D., STANDL, E., WILCOX, R. G., WILHELMSEN, L., BETTERIDGE, J., BIRKELAND, K., GOLAY, A., HEINE, R. J., KORÁNYI, L., LAAKSO, M., MOKÁŇ, M., NORKUS, A., PIRAGS, V., PODAR, T., SCHEEN, A., SCHERBAUM, W., SCHERNTHANER, G., SCHMITZ, O., ŠKRHA, J., SMITH, U. \& TATOŇ, J. Secondary prevention of macrovascular events in patients with type 2 diabetes in the PROactive Study (PROspective pioglitAzone Clinical Trial In macroVascular Events): a randomised controlled trial. The Lancet, 366, 1279-1289.

DUTTA-ROY, A. K. \& SINHA, A. K. 1987. Purification and properties of prostaglandin E1/prostacyclin receptor of human blood platelets. J Biol Chem, 262, 12685-91.

EIGENTHALER, M., ULLRICH, H., GEIGER, J., HORSTRUP, K., HONIG-LIEDL, P., WIEBECKE, D. \& WALTER, U. 1993. Defective nitrovasodilator-stimulated protein phosphorylation and calcium regulation in CGMP-dependent protein kinase-deficient human platelets of chronic myelocytic leukemia. J Biol Chem, 268, 13526-31.

FALATI, S., PATIL, S., GROSS, P. L., STAPLETON, M., MERRILL-SKOLOFF, G., BARRETT, N. E., PIXTON, K. L., WEILER, H., COOLEY, B., NEWMAN, D. K., NEWMAN, P. J., FURIE, B. C., FURIE, B. \& GIBBINS, J. M. 2006. Platelet PECAM-1 inhibits thrombus formation in vivo. Blood, 107, 53541.

FAN, X., SHI, P., DAI, J., LU, Y., CHEN, X., LIU, X., ZHANG, K., WU, X., SUN, Y., WANG, K., ZHU, L., ZHANG, C. C., ZHANG, J., CHEN, G. Q., ZHENG, J. \& LIU, J. 2014. Paired immunoglobulin-like receptor $B$ regulates platelet activation. Blood, 124, 2421-30.

FORMAN, B. M., CHEN, J. \& EVANS, R. M. 1997. Hypolipidemic drugs, polyunsaturated fatty acids, and eicosanoids are ligands for peroxisome proliferator-activated receptors alpha and delta. Proc Natl Acad Sci U S A, 94, 4312-7.

GABBI, C., WARNER, M. \& GUSTAFSSON, J.-Å. 2014. Action mechanisms of Liver X Receptors. Biochemical and Biophysical Research Communications, 446, 647-650.

GAMBARYAN, S., KOBSAR, A., HARTMANN, S., BIRSCHMANN, I., KUHLENCORDT, P. J., MULLERESTERL, W., LOHMANN, S. M. \& WALTER, U. 2008. NO-synthase-/NO-independent regulation of human and murine platelet soluble guanylyl cyclase activity. J Thromb Haemost, 6, 137684.

GAMBARYAN, S., KOBSAR, A., RUKOYATKINA, N., HERTERICH, S., GEIGER, J., SMOLENSKI, A., LOHMANN, S. M. \& WALTER, U. 2010. Thrombin and collagen induce a feedback inhibitory 
signaling pathway in platelets involving dissociation of the catalytic subunit of protein kinase A from an NFkappaB-IkappaB complex. J Biol Chem, 285, 18352-63.

GILIO, K., HARPER, M. T., COSEMANS, J. M., KONOPATSKAYA, O., MUNNIX, I. C., PRINZEN, L., LEITGES, M., LIU, Q., MOLKENTIN, J. D., HEEMSKERK, J. W. \& POOLE, A. W. 2010. Functional divergence of platelet protein kinase $C$ (PKC) isoforms in thrombus formation on collagen. $J$ Biol Chem, 285, 23410-9.

GKALIAGKOUSI, E., RITTER, J. \& FERRO, A. 2007. Platelet-derived nitric oxide signaling and regulation. Circ Res, 101, 654-62.

GOODWIN, A. M., SULLIVAN, K. M. \& D'AMORE, P. A. 2006. Cultured endothelial cells display endogenous activation of the canonical Wnt signaling pathway and express multiple ligands, receptors, and secreted modulators of Wnt signaling. Dev Dyn, 235, 3110-20.

GORMAN, R. R., BUNTING, S. \& MILLER, O. V. 1977. Modulation of human platelet adenylate cyclase by prostacyclin (PGX). Prostaglandins, 13, 377-88.

GOYERT, S. M., FERRERO, E. M., SEREMETIS, S. V., WINCHESTER, R. J., SILVER, J. \& MATTISON, A. C. 1986. Biochemistry and expression of myelomonocytic antigens. J Immunol, 137, 3909-14.

GUSHIKEN, F. C., PATEL, V., LIU, Y., PRADHAN, S., BERGERON, A. L., PENG, Y. \& VIJAYAN, K. V. 2008. Protein phosphatase 2A negatively regulates integrin alpha(Ilb)beta(3) signaling. J Biol Chem, 283, 12862-9.

HALL, K. J., HARPER, M. T., GILIO, K., COSEMANS, J. M., HEEMSKERK, J. W. \& POOLE, A. W. 2008. Genetic analysis of the role of protein kinase Ctheta in platelet function and thrombus formation. PLoS One, 3, e3277.

HALL, R. A., OSTEDGAARD, L. S., PREMONT, R. T., BLITZER, J. T., RAHMAN, N., WELSH, M. J. \& LEFKOWITZ, R. J. 1998. A C-terminal motif found in the beta2-adrenergic receptor, P2Y1 receptor and cystic fibrosis transmembrane conductance regulator determines binding to the $\mathrm{Na}+/ \mathrm{H}+$ exchanger regulatory factor family of PDZ proteins. Proc Natl Acad Sci U S A, 95, 8496-501.

HARDY, A. R., CONLEY, P. B., LUO, J., BENOVIC, J. L., POOLE, A. W. \& MUNDELL, S. J. 2005. P2Y1 and P2Y12 receptors for ADP desensitize by distinct kinase-dependent mechanisms. Blood, 105, 3552-60.

HARPER, M. T. \& POOLE, A. W. 2009. PKCtheta in platelet activation. Blood, 114, 489-91; author reply 491-2.

HARPER, M. T. \& POOLE, A. W. 2010. Diverse functions of protein kinase C isoforms in platelet activation and thrombus formation. J Thromb Haemost, 8, 454-62.

HASLAM, R. J., DICKINSON, N. T. \& JANG, E. K. 1999. Cyclic nucleotides and phosphodiesterases in platelets. Thromb Haemost, 82, 412-23.

HENSHALL, T. L., JONES, K. L., WILKINSON, R. \& JACKSON, D. E. 2001. Src homology 2 domaincontaining protein-tyrosine phosphatases, SHP-1 and SHP-2, are required for platelet endothelial cell adhesion molecule-1/CD31-mediated inhibitory signaling. J Immunol, 166, 3098-106.

HIDARI, K. I., WEYRICH, A. S., ZIMMERMAN, G. A. \& MCEVER, R. P. 1997. Engagement of P-selectin glycoprotein ligand-1 enhances tyrosine phosphorylation and activates mitogen-activated protein kinases in human neutrophils. J Biol Chem, 272, 28750-6.

HUANG, H. \& HE, X. 2008. Wnt/beta-catenin signaling: new (and old) players and new insights. Curr Opin Cell Biol, 20, 119-25.

JACKSON, D. E., KUPCHO, K. R. \& NEWMAN, P. J. 1997. Characterization of phosphotyrosine binding motifs in the cytoplasmic domain of platelet/endothelial cell adhesion molecule-1 (PECAM1) that are required for the cellular association and activation of the protein-tyrosine phosphatase, SHP-2. J Biol Chem, 272, 24868-75.

JANTZEN, H. M., MILSTONE, D. S., GOUSSET, L., CONLEY, P. B. \& MORTENSEN, R. M. 2001. Impaired activation of murine platelets lacking $\mathrm{G}$ alpha(i2). J Clin Invest, 108, 477-83. 
JONES, C. I., BARRETT, N. E., MORAES, L. A., GIBBINS, J. M. \& JACKSON, D. E. 2012. Endogenous inhibitory mechanisms and the regulation of platelet function. Methods Mol Biol, 788, 34166.

JONES, C. I., GARNER, S. F., MORAES, L. A., KAISER, W. J., RANKIN, A., BLOODOMICS, C., OUWEHAND, W. H., GOODALL, A. H. \& GIBBINS, J. M. 2009. PECAM-1 expression and activity negatively regulate multiple platelet signaling pathways. FEBS Lett, 583, 3618-24.

JONES, C. I., SAGE, T., MORAES, L. A., VAIYAPURI, S., HUSSAIN, U., TUCKER, K. L., BARRETT, N. E. \& GIBBINS, J. M. 2014. Platelet endothelial cell adhesion molecule-1 inhibits platelet response to thrombin and von Willebrand factor by regulating the internalization of glycoprotein Ib via AKT/glycogen synthase kinase-3/dynamin and integrin alphallbbeta3. Arterioscler Thromb Vasc Biol, 34, 1968-76.

JONES, K. L., HUGHAN, S. C., DOPHEIDE, S. M., FARNDALE, R. W., JACKSON, S. P. \& JACKSON, D. E. 2001. Platelet endothelial cell adhesion molecule-1 is a negative regulator of plateletcollagen interactions. Blood, 98, 1456-63.

JOSEPH, S. B., MCKILligIN, E., PEI, L., WATSON, M. A., COlLINS, A. R., LAFFITTE, B. A., CHEN, M., NOH, G., GOODMAN, J., HAGGER, G. N., TRAN, J., TIPPIN, T. K., WANG, X., LUSIS, A. J., HSUEH, W. A., LAW, R. E., COLLINS, J. L., WILLSON, T. M. \& TONTONOZ, P. 2002. Synthetic LXR ligand inhibits the development of atherosclerosis in mice. Proc Natl Acad Sci U S A, 99, 7604-9.

KARSHOVSKA, E., ZHAO, Z., BLANCHET, X., SCHMITT, M. M., BIDZHEKOV, K., SOEHNLEIN, O., VON HUNDELSHAUSEN, P., MATTHEIJ, N. J., COSEMANS, J. M., MEGENS, R. T., KOEPPEL, T. A., SCHOBER, A., HACKENG, T. M., WEBER, C. \& KOENEN, R. R. 2015. Hyperreactivity of junctional adhesion molecule A-deficient platelets accelerates atherosclerosis in hyperlipidemic mice. Circ Res, 116, 587-99.

KASHIWAGI, H., SHIRAGA, M., KATO, H., KAMAE, T., YAMAMOTO, N., TADOKORO, S., KURATA, Y., TOMIYAMA, Y. \& KANAKURA, Y. 2005. Negative regulation of platelet function by a secreted cell repulsive protein, semaphorin 3A. Blood, 106, 913-21.

KERSTEN, S., DESVERGNE, B. \& WAHLI, W. 2000. Roles of PPARs in health and disease. Nature, 405, 421-424.

KHARITONENKOV, A., CHEN, Z., SURES, I., WANG, H., SCHILLING, J. \& ULLRICH, A. 1997. A family of proteins that inhibit signalling through tyrosine kinase receptors. Nature, 386, 181-6.

KONOPATSKAYA, O., GILIO, K., HARPER, M. T., ZHAO, Y., COSEMANS, J. M., KARIM, Z. A., WHITEHEART, S. W., MOLKENTIN, J. D., VERKADE, P., WATSON, S. P., HEEMSKERK, J. W. \& POOLE, A. W. 2009. PKCalpha regulates platelet granule secretion and thrombus formation in mice. J Clin Invest, 119, 399-407.

LAURENT, P. A., SEVERIN, S., GRATACAP, M. P. \& PAYRASTRE, B. 2014. Class I PI 3-kinases signaling in platelet activation and thrombosis: PDK1/Akt/GSK3 axis and impact of PTEN and SHIP1. Adv Biol Regul, 54, 162-74.

LEAVESLEY, D. I., OLIVER, J. M., SWART, B. W., BERNDT, M. C., HAYLOCK, D. N. \& SIMMONS, P. J. 1994. Signals from platelet/endothelial cell adhesion molecule enhance the adhesive activity of the very late antigen-4 integrin of human CD34+ hemopoietic progenitor cells. J Immunol, 153, 4673-83.

LEE, C. H., CHAWLA, A., URBIZTONDO, N., LIAO, D., BOISVERT, W. A., EVANS, R. M. \& CURTISS, L. K. 2003. Transcriptional repression of atherogenic inflammation: modulation by PPARdelta. Science, 302, 453-7.

LI, D., CHEN, K., SINHA, N., ZHANG, X., WANG, Y., SINHA, A. K., ROMEO, F. \& MEHTA, J. L. 2005. The effects of PPAR-gamma ligand pioglitazone on platelet aggregation and arterial thrombus formation. Cardiovasc Res, 65, 907-12.

LYONS, A. B., COOPER, S. J., COLE, S. R. \& ASHMAN, L. K. 1988. Human myeloid differentiation antigens identified by monoclonal antibodies to the myelomonocytic leukemia cell line RC2A. Pathology, 20, 137-46. 
MA, P., CIERNIEWSKA, A., SIGNARVIC, R., CIESLAK, M., KONG, H., SINNAMON, A. J., NEUBIG, R. R., NEWMAN, D. K., STALKER, T. J. \& BRASS, L. F. 2012. A newly identified complex of spinophilin and the tyrosine phosphatase, SHP-1, modulates platelet activation by regulating $\mathrm{G}$ proteindependent signaling. Blood, 119, 1935-45.

MACAULAY, I. C., TIJSSEN, M. R., THIJSSEN-TIMMER, D. C., GUSNANTO, A., STEWARD, M., BURNS, P., LANGFORD, C. F., ELLIS, P. D., DUDBRIDGE, F., ZWAGINGA, J. J., WATKINS, N. A., VAN DER SCHOOT, C. E. \& OUWEHAND, W. H. 2007. Comparative gene expression profiling of in vitro differentiated megakaryocytes and erythroblasts identifies novel activatory and inhibitory platelet membrane proteins. Blood, 109, 3260-9.

MACDONALD, B. T., SEMENOV, M. V. \& HE, X. 2007. SnapShot: Wnt/beta-catenin signaling. Cell, 131, 1204.

MANGANELLO, J. M., DJELLAS, Y., BORG, C., ANTONAKIS, K. \& LE BRETON, G. C. 1999. Cyclic AMPdependent phosphorylation of thromboxane $A(2)$ receptor-associated Galpha(13). I Biol Chem, 274, 28003-10.

MASSBERG, S., SAUSBIER, M., KLATT, P., BAUER, M., PFEIFER, A., SIESS, W., FASSLER, R., RUTH, P., KROMBACH, F. \& HOFMANN, F. 1999. Increased adhesion and aggregation of platelets lacking cyclic guanosine 3',5'-monophosphate kinase I. J Exp Med, 189, 1255-64.

MAYANGLAMBAM, A., BHAVANASI, D., VIJAYAN, K. V. \& KUNAPULI, S. P. 2011. Differential dephosphorylation of the protein kinase C-zeta (PKCzeta) in an integrin alphallbbeta3dependent manner in platelets. Biochem Pharmacol, 82, 505-13.

MAZHARIAN, A., MORI, J., WANG, Y. J., HEISING, S., NEEL, B. G., WATSON, S. P. \& SENIS, Y. A. 2013. Megakaryocyte-specific deletion of the protein-tyrosine phosphatases Shp1 and Shp2 causes abnormal megakaryocyte development, platelet production, and function. Blood, 121, 420520.

MAZHARIAN, A., WANG, Y. J., MORI, J., BEM, D., FINNEY, B., HEISING, S., GISSEN, P., WHITE, J. G., BERNDT, M. C., GARDINER, E. E., NIESWANDT, B., DOUGLAS, M. R., CAMPBELL, R. D., WATSON, S. P. \& SENIS, Y. A. 2012. Mice lacking the ITIM-containing receptor G6b-B exhibit macrothrombocytopenia and aberrant platelet function. Sci Signal, 5, ra78.

MELLION, B. T., IGNARRO, L. J., OHLSTEIN, E. H., PONTECORVO, E. G., HYMAN, A. L. \& KADOWITZ, P. J. 1981. Evidence for the inhibitory role of guanosine 3', 5'-monophosphate in ADP-induced human platelet aggregation in the presence of nitric oxide and related vasodilators. Blood, 57, 946-55.

MELLOR, H. \& PARKER, P. J. 1998. The extended protein kinase C superfamily. Biochem J, 332 ( Pt 2), 281-92.

METZELAAR, M. J., KORTEWEG, J., SIXMA, J. J. \& NIEUWENHUIS, H. K. 1991. Biochemical characterization of PECAM-1 (CD31 antigen) on human platelets. Thromb Haemost, 66, 7007.

MIURA, Y., KAIBUCHI, K., ITOH, T., CORBIN, J. D., FRANCIS, S. H. \& TAKAI, Y. 1992. Phosphorylation of smg p21B/rap1B p21 by cyclic GMP-dependent protein kinase. FEBS Lett, 297, 171-4.

MODDERMAN, P. W., VON DEM BORNE, A. E. \& SONNENBERG, A. 1994. Tyrosine phosphorylation of $P$-selectin in intact platelets and in a disulphide-linked complex with immunoprecipitated pp60c-src. Biochem J, 299 ( Pt 3), 613-21.

MORAES, L. A., BARRETT, N. E., JONES, C. I., HOLBROOK, L. M., SPYRIDON, M., SAGE, T., NEWMAN, D. K. \& GIBBINS, J. M. 2010a. Platelet endothelial cell adhesion molecule-1 regulates collagenstimulated platelet function by modulating the association of phosphatidylinositol 3-kinase with Grb-2-associated binding protein-1 and linker for activation of T cells. J Thromb Haemost, 8, 2530-41.

MORAES, L. A., PAUL-CLARK, M. J., RICKMAN, A., FLOWER, R. J., GOULDING, N. J. \& PERRETTI, M. 2005a. Ligand-specific glucocorticoid receptor activation in human platelets. Blood, 106, 4167-4175. 
MORAES, L. A., PAUL-CLARK, M. J., RICKMAN, A., FLOWER, R. J., GOULDING, N. J. \& PERRETTI, M. 2005b. Ligand-specific glucocorticoid receptor activation in human platelets. Blood, 106, 4167-75.

MORAES, L. A., SPYRIDON, M., KAISER, W. J., JONES, C., SAGE, T., ATHERTON, R. \& GIBBINS, J. M. 2010b. Non-genomic effects of PPARY ligands: inhibition of GPVI-stimulated platelet activation. Journal of Thrombosis and Haemostasis, 8, 577-587.

MORAES, L. A., SPYRIDON, M., KAISER, W. J., JONES, C. I., SAGE, T., ATHERTON, R. E. \& GIBBINS, J. M. 2010c. Non-genomic effects of PPARgamma ligands: inhibition of GPVI-stimulated platelet activation. J Thromb Haemost, 8, 577-87.

MORAES, L. A., SWALES, K. E., WRAY, J. A., DAMAZO, A., GIBBINS, J. M., WARNER, T. D. \& BISHOPBAILEY, D. 2007. Nongenomic signaling of the retinoid $X$ receptor through binding and inhibiting Gq in human platelets. Blood, 109, 3741-4.

MORAES, L. A., VAIYAPURI, S., SASIKUMAR, P., ALI, M. S., KRIEK, N., SAGE, T. \& GIBBINS, J. M. 2013. Antithrombotic actions of statins involve PECAM-1 signaling. Blood, 122, 3188-96.

MORI, J., PEARCE, A. C., SPALTON, J. C., GRYGIELSKA, B., EBLE, J. A., TOMLINSON, M. G., SENIS, Y. A. \& WATSON, S. P. 2008. G6b-B inhibits constitutive and agonist-induced signaling by glycoprotein VI and CLEC-2. J Biol Chem, 283, 35419-27.

MUNDELL, S. J., JONES, M. L., HARDY, A. R., BARTON, J. F., BEAUCOURT, S. M., CONLEY, P. B. \& POOLE, A. W. 2006. Distinct roles for protein kinase $C$ isoforms in regulating platelet purinergic receptor function. Mol Pharmacol, 70, 1132-42.

MURUGAPPAN, S., TULUC, F., DORSAM, R. T., SHANKAR, H. \& KUNAPULI, S. P. 2004. Differential role of protein kinase $C$ delta isoform in agonist-induced dense granule secretion in human platelets. J Biol Chem, 279, 2360-7.

NAGAISHI, T., PAO, L., LIN, S. H., IIJIMA, H., KASER, A., QIAO, S. W., CHEN, Z., GLICKMAN, J., NAJJAR, S. M., NAKAJIMA, A., NEEL, B. G. \& BLUMBERG, R. S. 2006. SHP1 phosphatase-dependent T cell inhibition by CEACAM1 adhesion molecule isoforms. Immunity, 25, 769-81.

NAGY, B., JR., BHAVARAJU, K., GETZ, T., BYNAGARI, Y. S., KIM, S. \& KUNAPULI, S. P. 2009. Impaired activation of platelets lacking protein kinase C-theta isoform. Blood, 113, 2557-67.

NAIK, M. U., CAPLAN, J. L. \& NAIK, U. P. 2014. Junctional adhesion molecule-A suppresses platelet integrin alphallbbeta3 signaling by recruiting Csk to the integrin-c-Src complex. Blood, 123, 1393-402.

NAIK, M. U., STALKER, T. J., BRASS, L. F. \& NAIK, U. P. 2012. JAM-A protects from thrombosis by suppressing integrin alphallbbeta3-dependent outside-in signaling in platelets. Blood, 119, 3352-60.

NASDALA, I., WOLBURG-BUCHHOLZ, K., WOLBURG, H., KUHN, A., EBNET, K., BRACHTENDORF, G., SAMULOWITZ, U., KUSTER, B., ENGELHARDT, B., VESTWEBER, D. \& BUTZ, S. 2002. A transmembrane tight junction protein selectively expressed on endothelial cells and platelets. J Biol Chem, 277, 16294-303.

NEWLAND, S. A., MACAULAY, I. C., FLOTO, A. R., DE VET, E. C., OUWEHAND, W. H., WATKINS, N. A., LYONS, P. A. \& CAMPBELL, D. R. 2007. The novel inhibitory receptor G6B is expressed on the surface of platelets and attenuates platelet function in vitro. Blood, 109, 4806-9.

NEWMAN, P. J. 1997. The biology of PECAM-1. Journal of Clinical Investigation, 100, S25-S29.

NEWTON, A. C. 1997. Regulation of protein kinase C. Curr Opin Cell Biol, 9, 161-7.

NEWTON, J. P., BUCKLEY, C. D., JONES, E. Y. \& SIMMONS, D. L. 1997. Residues on both faces of the first immunoglobulin fold contribute to hemophilic binding sites of PECAM-1/CD31. Journal of Biological Chemistry, 272, 20555-20563.

O'BRIEN, J. J., RAY, D. M., SPINELLI, S. L., BLUMBERG, N., TAUBMAN, M. B., FRANCIS, C. W., WITTLIN, S. D. \& PHIPPS, R. P. 2007. The platelet as a therapeutic target for treating vascular diseases and the role of eicosanoid and synthetic PPARY ligands. Prostaglandins \& Other Lipid Mediators, 82, 68-76. 
PEARS, C. J., THORNBER, K., AUGER, J. M., HUGHES, C. E., GRYGIELSKA, B., PROTTY, M. B., PEARCE, A. C. \& WATSON, S. P. 2008. Differential roles of the PKC novel isoforms, PKCdelta and PKCepsilon, in mouse and human platelets. PLoS One, 3, e3793.

PIALI, L., ALBELDA, S. M., BALDWIN, H. S., HAMMEL, P., GISLER, R. H. \& IMHOF, B. A. 1993. Murine platelet endothelial cell adhesion molecule (PECAM-1)/CD31 modulates beta 2 integrins on lymphokine-activated killer cells. Eur J Immunol, 23, 2464-71.

PRADHAN, S., ALREHANI, N., PATEL, V., KHATLANI, T. \& VIJAYAN, K. V. 2010. Cross-talk between serine/threonine protein phosphatase $2 \mathrm{~A}$ and protein tyrosine phosphatase $1 \mathrm{~B}$ regulates SrC activation and adhesion of integrin alphallbbeta3 to fibrinogen. J Biol Chem, 285, 29059-68.

PULA, G., SCHUH, K., NAKAYAMA, K., NAKAYAMA, K. I., WALTER, U. \& POOLE, A. W. 2006. PKCdelta regulates collagen-induced platelet aggregation through inhibition of VASP-mediated filopodia formation. Blood, 108, 4035-44.

PUMPHREY, N. J., TAYLOR, V., FREEMAN, S., DOUGLAS, M. R., BRADFIELD, P. F., YOUNG, S. P., LORD, J. M., WAKELAM, M. J., BIRD, I. N., SALMON, M. \& BUCKLEY, C. D. 1999. Differential association of cytoplasmic signalling molecules SHP-1, SHP-2, SHIP and phospholipase Cgamma1 with PECAM-1/CD31. FEBS Lett, 450, 77-83.

RADOMSKI, M. W., PALMER, R. M. \& MONCADA, S. 1987. Comparative pharmacology of endothelium-derived relaxing factor, nitric oxide and prostacyclin in platelets. $\mathrm{Br} J$ Pharmacol, 92, 181-7.

RADOMSKI, M. W., PALMER, R. M. \& MONCADA, S. 1990a. Characterization of the L-arginine:nitric oxide pathway in human platelets. Br J Pharmacol, 101, 325-8.

RADOMSKI, M. W., PALMER, R. M. \& MONCADA, S. 1990b. An L-arginine/nitric oxide pathway present in human platelets regulates aggregation. Proc Natl Acad Sci U S A, 87, 5193-7.

RATHORE, V., STAPLETON, M. A., HILLERY, C. A., MONTGOMERY, R. R., NICHOLS, T. C., MERRICKS, E. P., NEWMAN, D. K. \& NEWMAN, P. J. 2003. PECAM-1 negatively regulates GPIb/V/IX signaling in murine platelets. Blood, 102, 3658-64.

REID, H. M. \& KINSELLA, B. T. 2003. The alpha, but not the beta, isoform of the human thromboxane A2 receptor is a target for nitric oxide-mediated desensitization. Independent modulation of Tp alpha signaling by nitric oxide and prostacyclin. J Biol Chem, 278, 51190-202.

RELOU, I. A., GORTER, G., FERREIRA, I. A., VAN RIJN, H. J. \& AKKERMAN, J. W. 2003. Platelet endothelial cell adhesion molecule-1 (PECAM-1) inhibits low density lipoprotein-induced signaling in platelets. J Biol Chem, 278, 32638-44.

ROBITAILLE, J., IZZI, L., DANIELS, E., ZELUS, B., HOLMES, K. V. \& BEAUCHEMIN, N. 1999. Comparison of expression patterns and cell adhesion properties of the mouse biliary glycoproteins Bbgp1 and Bbgp2. Eur J Biochem, 264, 534-44.

ROCHDI, M. D., WATIER, V., LA MADELEINE, C., NAKATA, H., KOZASA, T. \& PARENT, J. L. 2002. Regulation of GTP-binding protein alpha q (Galpha q) signaling by the ezrin-radixin-moesinbinding phosphoprotein-50 (EBP50). J Biol Chem, 277, 40751-9.

RUSSO, I., TRAVERSA, M., BONOMO, K., DE SALVE, A., MATTIELLO, L., DEL MESE, P., DORONZO, G., CAVALOT, F., TROVATI, M. \& ANFOSSI, G. 2010. In central obesity, weight loss restores platelet sensitivity to nitric oxide and prostacyclin. Obesity (Silver Spring), 18, 788-97.

SALAHELDEEN, E., KURIO, H., HOWIDA, A. \& IIDA, H. 2012. Molecular cloning and localization of a CEACAM2 isoform, CEACAM2-L, expressed in spermatids in mouse testis. Mol Reprod Dev, 79, 843-52.

SAUER, W. H., CAPPOLA, A. R., BERLIN, J. A. \& KIMMEL, S. E. 2006. Insulin sensitizing pharmacotherapy for prevention of myocardial infarction in patients with diabetes mellitus. The American journal of cardiology, 97, 651-654.

SCHULTESS, J., DANIELEWSKI, O. \& SMOLENSKI, A. P. 2005. Rap1GAP2 is a new GTPase-activating protein of Rap1 expressed in human platelets. Blood, 105, 3185-92.

SEMENOV, M. V., HABAS, R., MACDONALD, B. T. \& HE, X. 2007. SnapShot: Noncanonical Wnt Signaling Pathways. Cell, 131, 1378. 
SENIS, Y. A. 2013. Protein-tyrosine phosphatases: a new frontier in platelet signal transduction. J Thromb Haemost, 11, 1800-13.

SENIS, Y. A., TOMLINSON, M. G., GARCIA, A., DUMON, S., HEATH, V. L., HERBERT, J., COBBOLD, S. P., SPALTON, J. C., AYMAN, S., ANTROBUS, R., ZITZMANN, N., BICKNELL, R., FRAMPTON, J., AUTHI, K. S., MARTIN, A., WAKELAM, M. J. \& WATSON, S. P. 2007. A comprehensive proteomics and genomics analysis reveals novel transmembrane proteins in human platelets and mouse megakaryocytes including G6b-B, a novel immunoreceptor tyrosine-based inhibitory motif protein. Mol Cell Proteomics, 6, 548-64.

SERINI, G., VALDEMBRI, D., ZANIVAN, S., MORTERRA, G., BURKHARDT, C., CACCAVARI, F., ZAMMATARO, L., PRIMO, L., TAMAGNONE, L., LOGAN, M., TESSIER-LAVIGNE, M., TANIGUCHI, M., PUSCHEL, A. W. \& BUSSOLINO, F. 2003. Class 3 semaphorins control vascular morphogenesis by inhibiting integrin function. Nature, 424, 391-7.

SHENOLIKAR, S., VOLTZ, J. W., CUNNINGHAM, R. \& WEINMAN, E. J. 2004. Regulation of ion transport by the NHERF family of PDZ proteins. Physiology (Bethesda), 19, 362-9.

SIDHU, J. S., COWAN, D., TOOZE, J. A. \& KASKI, J.-C. 2004. Peroxisome proliferator-activated receptor- $\gamma$ agonist rosiglitazone reduces circulating platelet activity in patients without diabetes mellitus who have coronary artery disease. American Heart Journal, 147, 10321037.

SMOLENSKI, A. 2012. Novel roles of cAMP/cGMP-dependent signaling in platelets. J Thromb Haemost, 10, 167-76.

SPYRIDON, M., MORAES, L. A., JONES, C. I., SAGE, T., SASIKUMAR, P., BUCCI, G. \& GIBBINS, J. M. 2011. LXR as a novel antithrombotic target. Blood, 117, 5751-61.

STALKER, T. J., WU, J., MORGANS, A., TRAXLER, E. A., WANG, L., CHATTERJEE, M. S., LEE, D., QUERTERMOUS, T., HALL, R. A., HAMMER, D. A., DIAMOND, S. L. \& BRASS, L. F. 2009. Endothelial cell specific adhesion molecule (ESAM) localizes to platelet-platelet contacts and regulates thrombus formation in vivo. J Thromb Haemost, 7, 1886-96.

STEele, B. M., hARPER, M. T., MACAULAY, I. C., MORRELL, C. N., PEREZ-TAMAYO, A., FOY, M., HABAS, R., POOLE, A. W., FITZGERALD, D. J. \& MAGUIRE, P. B. 2009. Canonical Wnt signaling negatively regulates platelet function. Proc Natl Acad Sci U S A, 106, 19836-41.

STEELE, B. M., HARPER, M. T., SMOLENSKI, A. P., ALKAZEMI, N., POOLE, A. W., FITZGERALD, D. J. \& MAGUIRE, P. B. 2012. WNT-3a modulates platelet function by regulating small GTPase activity. FEBS Lett, 586, 2267-72.

STEFANINI, L., BOULAFTALI, Y., OUELLETTE, T. D., HOLINSTAT, M., DESIRE, L., LEBLOND, B., ANDRE, P., CONLEY, P. B. \& BERGMEIER, W. 2012. Rap1-Rac1 circuits potentiate platelet activation. Arterioscler Thromb Vasc Biol, 32, 434-41.

STEFANINI, L., PAUL, D. S., ROBLEDO, R. F., CHAN, E. R., GETZ, T. M., CAMPBELL, R. A., KECHELE, D. O., CASARI, C., PIATT, R., CARON, K. M., MACKMAN, N., WEYRICH, A. S., PARROTT, M. C., BOULAFTALI, Y., ADAMS, M. D., PETERS, L. L. \& BERGMEIER, W. 2015. RASA3 is a critical inhibitor of RAP1-dependent platelet activation. J Clin Invest, 125, 1419-32.

SUN, Q. H., DELISSER, H. M., ZUKOWSKI, M. M., PADDOCK, C., ALBELDA, S. M. \& NEWMAN, P. J. 1996. Individually distinct Ig homology domains in PECAM-1 regulate hemophilic binding and modulate receptor affinity. Journal of Biological Chemistry, 271, 11090-11098.

TAKAHASHI, T., FOURNIER, A., NAKAMURA, F., WANG, L. H., MURAKAMI, Y., KALB, R. G., FUJISAWA, H. \& STRITTMATTER, S. M. 1999. Plexin-neuropilin-1 complexes form functional semaphorin$3 A$ receptors. Cell, 99, 59-69.

TAKAI, T. 2005. Paired immunoglobulin-like receptors and their MHC class I recognition. Immunology, 115, 433-40.

TAMAGNONE, L., ARTIGIANI, S., CHEN, H., HE, Z., MING, G. I., SONG, H., CHEDOTAL, A., WINBERG, M. L., GOODMAN, C. S., POO, M., TESSIER-LAVIGNE, M. \& COMOGLIO, P. M. 1999. Plexins are a large family of receptors for transmembrane, secreted, and GPI-anchored semaphorins in vertebrates. Cell, 99, 71-80. 
TANAKA, Y., ALBELDA, S. M., HORGAN, K. J., VAN SEVENTER, G. A., SHIMIZU, Y., NEWMAN, W., HALLAM, J., NEWMAN, P. J., BUCK, C. A. \& SHAW, S. 1992. CD31 expressed on distinctive T cell subsets is a preferential amplifier of beta 1 integrin-mediated adhesion. J Exp Med, 176, 245-53.

TANGIRALA, R. K., BISCHOFF, E. D., JOSEPH, S. B., WAGNER, B. L., WALCZAK, R., LAFFITTE, B. A., DAIGE, C. L., THOMAS, D., HEYMAN, R. A., MANGELSDORF, D. J., WANG, X., LUSIS, A. J., TONTONOZ, P. \& SCHULMAN, I. G. 2002. Identification of macrophage liver $X$ receptors as inhibitors of atherosclerosis. Proc Natl Acad Sci U S A, 99, 11896-901.

THAI LE, M., ASHMAN, L. K., HARBOUR, S. N., HOGARTH, P. M. \& JACKSON, D. E. 2003. Physical proximity and functional interplay of PECAM-1 with the Fc receptor Fc gamma Rlla on the platelet plasma membrane. Blood, 102, 3637-45.

THAI, L. M., ASHMAN, L. K., HARBOUR, S. N., HOGARTH, P. M. \& JACKSON, D. E. 2003. Physical proximity and functional interplay of PECAM-1 with the Fc receptor Fc gamma Rlla on the platelet plasma membrane. Blood, 102, 3637-3645.

THOMAS, D. H., GETZ, T. M., NEWMAN, T. N., DANGELMAIER, C. A., CARPINO, N., KUNAPULI, S. P., TSYGANKOV, A. Y. \& DANIEL, J. L. 2010. A novel histidine tyrosine phosphatase, TULA-2, associates with Syk and negatively regulates GPVI signaling in platelets. Blood, 116, 2570-8.

THOMAS, G., FARHAT, M. Y. \& RAMWELL, P. W. 1990. Effect of L-arginine and substituted arginine compounds on platelet aggregation: role of endothelium. Thromb Res, 60, 425-9.

THOMPSON, N. T., SCRUTTON, M. C. \& WALLIS, R. B. 1986. Particle volume changes associated with light transmittance changes in the platelet aggregometer: dependence upon aggregating agent and effectiveness of stimulus. Thromb Res, 41, 615-26.

TYMVIOS, C., MOORE, C., JONES, S., SOLOMON, A., SANZ-ROSA, D. \& EMERSON, M. 2009. Platelet aggregation responses are critically regulated in vivo by endogenous nitric oxide but not by endothelial nitric oxide synthase. Br J Pharmacol, 158, 1735-42.

UNSWORTH, A. J., FINNEY, B. A., NAVARRO-NUNEZ, L., SEVERIN, S., WATSON, S. P. \& PEARS, C. J. 2012. Protein kinase Cepsilon and protein kinase Ctheta double-deficient mice have a bleeding diathesis. J Thromb Haemost, 10, 1887-94.

VAN GEET, C., IZZI, B., LABARQUE, V. \& FRESON, K. 2009. Human platelet pathology related to defects in the G-protein signaling cascade. J Thromb Haemost, 7 Suppl 1, 282-6.

VARON, D., JACKSON, D. E., SHENKMAN, B., DARDIK, R., TAMARIN, I., SAVION, N. \& NEWMAN, P. J. 1998. Platelet/endothelial cell adhesion molecule-1 serves as a costimulatory agonist receptor that modulates integrin-dependent adhesion and aggregation of human platelets. Blood, 91, 500-7.

VIENNOIS, E., MOUZAT, K., DUFOUR, J., MOREL, L., LOBACCARO, J.-M. \& BARON, S. 2012. Selective liver $\mathrm{X}$ receptor modulators (SLiMs): What use in human health? Molecular and Cellular Endocrinology, 351, 129-141.

VIENNOIS, E., POMMIER, A. J., MOUZAT, K., OUMEDDOUR, A., HAJJAJ, F.-Z. E., DUFOUR, J., CAIRA, F., VOLLE, D. H., BARON, S. \& LOBACCARO, J.-M. A. 2011. Targeting liver $X$ receptors in human health: deadlock or promising trail? Expert opinion on therapeutic targets, 15, 219-232.

WALDMANN, R., NIEBERDING, M. \& WALTER, U. 1987. Vasodilator-stimulated protein phosphorylation in platelets is mediated by CAMP- and cGMP-dependent protein kinases. Eur J Biochem, 167, 441-8.

WARDELL, M. R., REYNOLDS, C. C., BERNDT, M. C., WALLACE, R. W. \& FOX, J. E. 1989. Platelet glycoprotein Ib beta is phosphorylated on serine 166 by cyclic AMP-dependent protein kinase. J Biol Chem, 264, 15656-61.

WEE, J. L. \& JACKSON, D. E. 2005. The Ig-ITIM superfamily member PECAM-1 regulates the "outsidein" signaling properties of integrin alpha(IIb)beta3 in platelets. Blood, 106, 3816-23.

WÓJCICKA, G., JAMROZ-WIŚNIEWSKA, A., HOROSZEWICZ, K. \& BEŁTOWSKI, J. 2015. Liver X receptors (LXRs). Part I: Structure, function, regulation of activity, and role in lipid metabolism 
Receptory wątrobowe X (LXR). Część I: Budowa, funkcja, regulacja aktywności i znaczenie w metabolizmie lipidów. Journal cover, 69.

WONG, C., LIU, Y., YIP, J., CHAND, R., WEE, J. L., OATES, L., NIESWANDT, B., REHEMAN, A., NI, H., BEAUCHEMIN, N. \& JACKSON, D. E. 2009. CEACAM1 negatively regulates platelet-collagen interactions and thrombus growth in vitro and in vivo. Blood, 113, 1818-28.

WU, X. W. \& LIAN, E. C. 1997. Binding properties and inhibition of platelet aggregation by a monoclonal antibody to CD31 (PECAM-1). Arterioscler Thromb Vasc Biol, 17, 3154-8.

YANG, J., WU, J., JIANG, H., MORTENSEN, R., AUSTIN, S., MANNING, D. R., WOULFE, D. \& BRASS, L. F. 2002. Signaling through Gi family members in platelets. Redundancy and specificity in the regulation of adenylyl cyclase and other effectors. J Biol Chem, 277, 46035-42.

YIP, J., ALSHAHRANI, M., BEAUCHEMIN, N. \& JACKSON, D. E. 2015. CEACAM1 regulates integrin alphallbbeta3-mediated functions in platelets. Platelets, 1-10.

ZHAO, T. \& NEWMAN, P. J. 2001. Integrin activation by regulated dimerization and oligomerization of platelet endothelial cell adhesion molecule (PECAM)-1 from within the cell. J Cell Biol, 152, 65-73.

ZHENG, J., UMIKAWA, M., CUI, C., LI, J., CHEN, X., ZHANG, C., HUYNH, H., KANG, X., SILVANY, R., WAN, X., YE, J., CANTO, A. P., CHEN, S. H., WANG, H. Y., WARD, E. S. \& ZHANG, C. C. 2012. Inhibitory receptors bind ANGPTLs and support blood stem cells and leukaemia development. Nature, 485, 656-60. 


\section{Figure 1. ITIM Signaling}

When ITIM-bearing receptors bind their ligand they cluster and the ITIM domains are phosphorylated. The phosphorylated ITIM domains recruit phosphastases through their SH2 domains, bringing them into close proximity with their substrates. The phosphatases SHP1/2 and SHIP1/2 dephosphorylate PI3K, LAT and PLCY2 and other molecules in the signaling pathways evoked by ITAM containing / linked receptors, such as GPVI, causing inactivation and contributing to negative regulation. The phosphatases recruited by ITIMs are also able to negatively regulate PI3K downstream of GPCRs, contributing negative regulation to non-ITAM signaling pathways.

\section{Figure 2. Intracellular nuclear receptor signaling.}

Several intracellular nuclear receptors have been identified and characterised in human platelets including the peroxisome proliferator activating receptors (PPAR)s, PPAR $\alpha, P P A R \beta / \delta$ and PPAR $\gamma$, the retinoid $X$ receptor (RXR), liver $X$ receptor (LXR), farnesoid $X$ receptor (FXR) and Glucocorticoid receptor (GR). The nuclear receptors are believed to negatively regulate platelet activity through various mechanisms following activation by their ligands, although these mechanisms are not well characterised. Both PPAR $\alpha$ and PPAR $\beta / \delta$ are thought to negatively regulate platelet function through regulation of CAMP levels, whilst PPARY and LXR receptors interact with and inhibit components of early GPVI signaling. In contrast RXR and GR appear to inhibit Gq signaling events. Grey lines represent platelet agonist signaling and black arrows represent the pathways or proteins that are modulated by nuclear receptor agonists in platelets.

\section{Figure 3. Negative regulators of small GTPases and integrin $\alpha_{\| 1} \beta_{3}$}

RASA3 inhibits RAPIb, preventing signal transduction that enables integrin $\alpha_{\| 1} \beta_{3}$ activation until PI3K activation downstream of Gi-coupled P2Y12 inhibits RASA3. Wnt 3a activates the $\beta$-catenin signaling pathway that negatively regulates small GTPases including Rac1 and Rap1 that underpin integrin activation. The neuropilin-1-plexin A complex is activated by semaphorin $3 \mathrm{~A}$ which also negatively regulates Rac1. JAM-A inhibits c-Src-dependent integrin $\alpha_{\| 1} \beta_{3}$ outside-in signaling through activation of Csk which negatively regulates c-Src. Stimulation with agonists causes dissociation of JAM-A from integrin $\alpha_{\| b} \beta_{3}$, reducing Csk activity and enabling activation of c-Src mediated integrin $\alpha_{\| b} \beta_{3}$ outside-in signaling. Semaphorin $3 A$ is believed to activate the neuropilin-1 plexin A complex which inhibits Rac1 causing inhibition of integrin $\alpha_{\| 1 b} \beta_{3}$ activation.

\section{Figure 4. Platelet derived inhibitors of platelet function}

Well characterised activatory pathways (black) are regulated by multiple inhibitory pathways that regulate platelet responses to support their role in hemostasis. Receptors that signal through ITIMs (blue) recuits SHP1/2 and SHIP1/2 in close proximity to ITAM receptors where they de-phosphorylate components of activation pathways, inactivating them to provide negative regulation. Small GTPases regulate several important process in platelets such as granule secretion and integrin $\alpha_{\| 1} \beta_{3}$ activation and so inhibitors of small GTPases (yellow) such as RASA3 and Wnt3a / $\beta$-catenin provide negative regulation for these key events. PKA and PKG are inhibitory kinases that are regulated by cyclic nucleotides (green), although these pathways are primarily regulated by non-platelet derived inhibitors they are also potentially regulated by platelet derived NO and non-cAMP dependent PKA activation. Other negative regulators (purple) such as phosphatases and kinases that regulate 
receptor desensitisation do not easily fit into discrete categories and mediate negative feedback via diverse mechanisms. 